\title{
PLANT PARASITIC NEMATODES ASSOCIATED WITH SELECTED AGRICULTURAL SOILS IN KWARA STATE, NIGERIA
}

\author{
Ahmed, O., Izuogu, N. B., Baba, H. S \& Kalejaiye, N. A \\ Department of Crop Protection Faculty of Agriculture University of llorin PMB 1515 llorin, Nigeria \\ Corresponding author email: ahmelad2007@yahoo.com

\section{ABSTRACT}

Plant parasitic nematodes have caused huge yield loss on all agricultural crops. Knowledge of the type and quantity of these pathogens in soils is an indication of the risk of disease development in the crops grown on the soils. This study was carried out to determine the plant parasitic nematode composition of selected agricultural soils in Kwara State, Nigeria. Three sample locations from each of the forest and savannah agro-ecological zones of the state were selected for the study. Soil samples were taken from the rhizosphere of five crops commonly grown in each of the six sample locations (Celosia sp. Cowpea, Maize, Soybean and Teak) using soil auger. Nematodes were extracted using the modified Bearmann technique and the nematodes were identified using standard identification key. The identity of the nematodes was confirmed at the International Institute for Tropical Agriculture (IITA), Ibadan. A total of six nematode genera namely, Meloidogyne sp., Helicotylenchus sp., Scutellonema sp., Pratylenchus sp., Rotylenchus sp., and Tylenchus sp. were isolated with Meloidogyne sp. having the highest frequency of occurrence in most of the sampled locations and crops. The implication of nematodes in agricultural soils is discussed.

Key words: Nematodes; Agricultural soils; Kwara State; Agro-ecology 


\section{INTRODUCTION}

Plant parasitic nematodes are non-segmented, bilaterally symmetrical worm-like invertebrates that possess a body cavity and a complete digestive system but lacks respiratory and circulatory systems (Chitwood, 2002). Nematodes are found in all agricultural soils where they play different roles. According to Ingham and Moidenke (2000), they can help in nutrient cycling. Nutrients such as ammonium (NH4+), stored in the bodies of bacteria and fungi, are released when nematodes eat them. The bacteria and fungi contain more nitrogen than the nematodes need, so the excess is released into the soil in a more stable form where it can be used by plants or other soil organisms. Nematodes also physically break down organic matter which increases its surface area, making it easier for other organisms to break it down further. They can also bring about dispersal of microbes. Bacteria and fungi cannot move around in the soil without 'hitching a ride' inside or on the back of nematodes.

Nematodes are common economic pests of agricultural crops causing considerable reduction in the yield of many crops including vegetables (Nchore et al., 2010). Yield losses normally results from changes brought about in the morphology and physiology of the roots of affected crops.

Chitwood (2003) reported that plant parasitic nematodes cause annual crop losses estimated at USDI 25 billion worldwide.

All crops are susceptible to nematodes (Gregory et al., 2017). Total crop failures may occur when crops are planted in areas with high nematode population levels (Noling, 2012). Plant symptoms which develop in response to nematode parasitism are generally those associated with root dysfunction (Noling, 2012). Development of small, stunted and chlorotic plants generally reflects reduced water and nutrient uptake caused by injury to the root system. The damage to plant tissues by nematodes infecting the shoot includes reduced vigor, distortion of plants parts and death of infected tissues depending upon the nematode species (Lambert and Bekel, 2002).

Damages due to plant parasitic nematodes have been reported on sugar cane (Afolami et al, 2014) Musa spp. (Okafor et al, 2015) and other crops in Nigeria. Nematode disease episodes may cause losses of, up to $80 \%$, on vegetables (Galip, 2007; Nchore et al., 2011).

There have been several other reports on the effect of plant parasitic nematodes on the crops they parasitize and their management (Jackson, 1962; Egunjobi, 2014; Talwana et al, 2016; Baba et al, 2018). There is, however, limited available reports on the diversity of nematodes populations in agricultural soils particularly in Kwara State, Nigeria. This study was, therefore, carried out to provide information on the types of plant parasitic nematodes associated with the soils. The information will no doubt help in informing farmers on the likely risks of disease development in 
crops planted in the soils with the view to planning effective management strategies to forestall the problem.

\section{MATERIALS AND METHODS \\ Description of the study areas}

Soil samples were collected from six locations in Kwara State. Three of the six locations belong to the Forest agro-ecology of the state while the other three locations belong to the Savannah agroecology of the state. The soil samples were taken from five commonly grown crops in all the six locations. The three locations selected from forest agro-ecology were Ifelodun, Offa and Oyun Local Government Areas and those from the savannah agro-ecology were llorin East, llorin South and Moro Local Government Areas. The five commonly grown crops in the sampled areas were Celosia sp. Cowpea, Maize, Soybean and Teak. Table 1 gives the summary of the description of the sample areas. The location of the sample areas on map is shown in Table 1.

\section{Table1: List of sampling sites}

\begin{tabular}{cccc}
\hline $\begin{array}{c}\text { Sample } \\
\text { No }\end{array}$ & Site location & GPS Coordinates & Classification \\
\hline \multirow{2}{*}{ S1 } & Ilorin South & Lat $8.4347^{\circ} \mathrm{N}$ & \\
& & Long $4.6657^{\circ} \mathrm{E}$ & Savannah agro ecology \\
S2 & llorin East & Lat $8.6083^{\circ} \mathrm{N}$ Lat & \\
& & $4.7899^{\circ} \mathrm{E}$ & Savannah agro ecology \\
S3 & Ifelodun & $5.5381^{\circ} \mathrm{N}$ Long & \\
& & $5.1432^{\circ} \mathrm{E}$ & Forest agro ecology \\
S4 & Moro & Lat $8.8449^{\circ} \mathrm{N}$ Long & Savannah agro ecology \\
& & $4.5567^{\circ} \mathrm{E}$ & \\
S5 & Offa & Lat $8.1393^{\circ} \mathrm{N}$ Long & Forest agro ecology \\
& & $4.7174^{\circ} \mathrm{E}$ & \\
S6 & Oyun & Lat $8.1633^{\circ} \mathrm{N}$ Long & Forest agro ecology \\
\hline
\end{tabular}

Source: Authors' field survey (2018) 


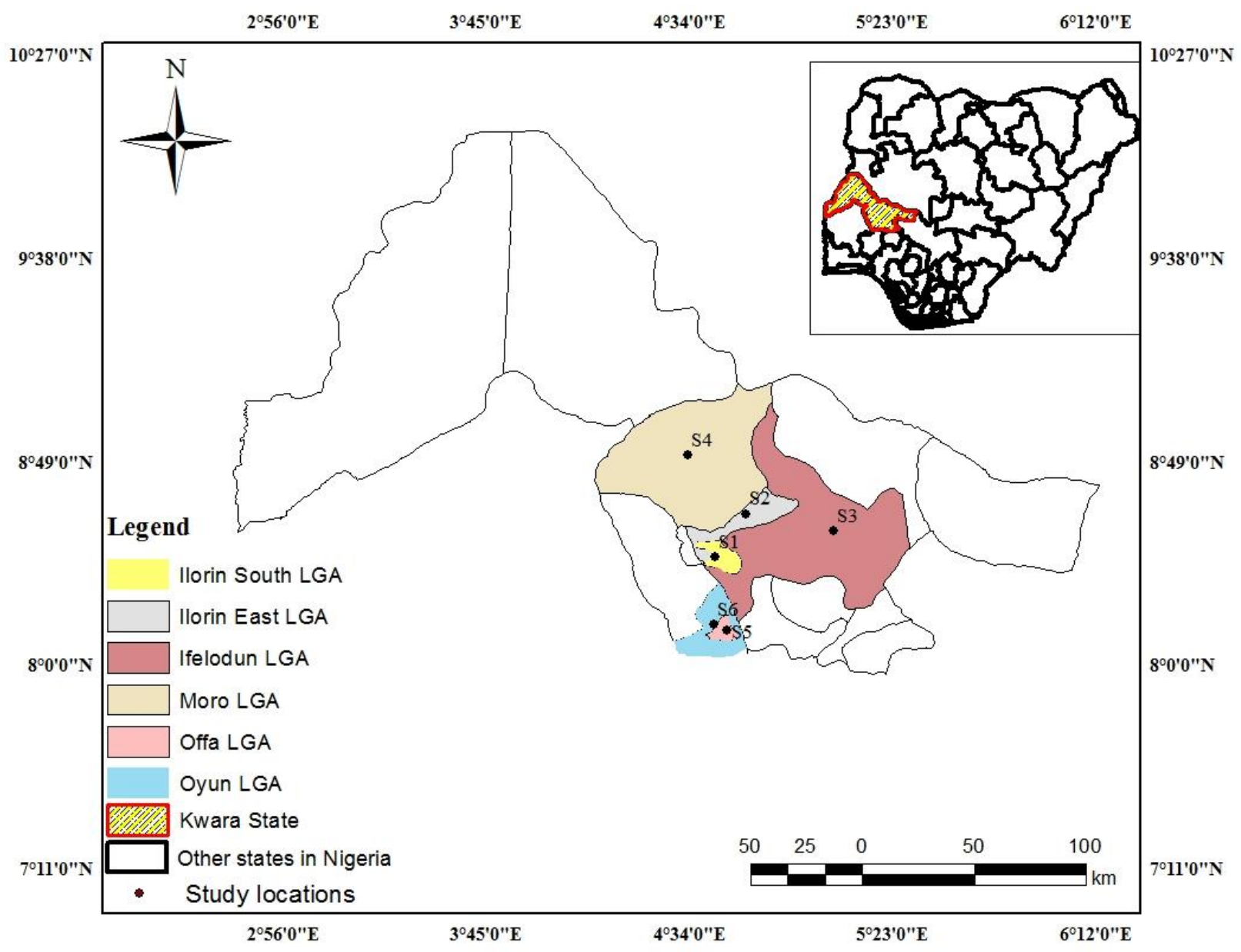

Plate 1: Map of Kwara State showing the sampling locations

\section{Soil Samples Collection}

Three farms under intensive production of each crop were randomly selected from each of the areas described above. Soil samples were taken from the rhizosphere of each crop in each farm from five points using a soil auger. The soil auger was sterilized using ethanol after every sampling point to avoid cross contamination.

The soil samples collected from all the five points in each crop farm were mixed in a bucket to make one composite sample. A $1 \mathrm{~kg}$ of soil was then re-sampled from the composite sample, put in plastic bags. All the samples were later transported to the Research Laboratory of the Department of Crop Protection Faculty of Agriculture, University of llorin for extraction of nematodes. 


\section{Extraction and Identification of Nematodes}

Nematodes were extracted using the modified Bearmann technique as described by Kleynhans, (1999). Soil lumps were broken, stones and plant debris removed. 200 grams of the sampled soil was spread evenly on a circle of double ply paper towel (serviette) supported on a coarse meshed plastic screen standing in a plastic container. Water was added to the container until the soil was thoroughly wet but not immersed. The container was covered with a large Petri dish to reduce evaporation of the water. The set up was left for at least 24 hours. Soil was then removed, discarded and the nematode suspension was poured from the container into sample bottles. Preliminary identification and counting of the extracted nematodes were carried out. The nematodes were identified using nematode identification key as described by Armen et al. (1977), counting was done by drawing $2 \mathrm{ml}$ of nematode suspension with a micropipette, the suspension was then placed into a counting dish where counting was done under a compound microscope at 40x magnification. Further identification and counting were requested in the Pathology Laboratory of the International Institute for Tropical Agriculture (IITA) for confirmation.

\section{Data analysis}

Data on the occurrence of the different types and the numbers of nematodes was recorded and transformation was done using log transformation. Analysis of variance was carried out using the SPSS Statistical package version 21. Comparison of means was done using the Tukey's HSD at $5 \%$ level of significance.

\section{RESULTS}

A total of six nematode genera were isolated and identified in all the sampled soils in the different agro ecological zones of Kwara State. They were; Meloidogyne sp., Helicotylenchus sp., Scutellonema sp., Pratylenchus sp., Rotylenchus sp., and Tylenchus sp. The nematodes and their population (mean number) are shown in Table 2. The results showed a significantly different $(p<0.05)$ mean number of Meloidogyne sp. and Helicotylenchus sp while there was no significant difference $(p>0.05)$ in the mean number of the other nematodes. The mean number of Meloidogyne sp. was highest in Offa (1.62) followed by llorin East (0.99). The mean number of Helicotylenchus sp. was highest in llorin east (2.90) followed by llorin south (1.25) and Offa (1.03). 
Table 2: Occurrence of Nematodes in the Rhizosphere of soils in the selected agro ecologies of Kwara State

\begin{tabular}{|c|c|c|c|c|c|c|}
\hline \multirow[b]{3}{*}{ Location } & \multicolumn{6}{|c|}{ Mean number of Nematodes $200 \mathrm{~g}-{ }^{-1}$ dry weight of soil } \\
\hline & Meloidogyne & Helicotylenchus & Scutellonema & Pratylenchus & Rotylenchus & \\
\hline & sp. & sp. & sp. & sp. & sp. & Tylenchus sp. \\
\hline Ifelodun & $0.93 a$ & $0.71 \mathrm{a}$ & 0.71 & 0.71 & 0.71 & 0.71 \\
\hline Ilorin south & $0.93 a$ & $1.25 a$ & 0.82 & 0.93 & 0.71 & 0.82 \\
\hline Ilorin east & $0.99 \mathrm{ab}$ & $2.90 \mathrm{~b}$ & 0.82 & 1.04 & 0.82 & 0.71 \\
\hline Moro & $0.71 \mathrm{a}$ & $0.88 a$ & 0.71 & 0.71 & 0.71 & 0.71 \\
\hline Offa & $1.62 b$ & $1.03 a$ & 0.82 & 0.71 & 0.71 & 0.82 \\
\hline Oyun & $0.71 \mathrm{a}$ & $0.88 a$ & 0.71 & 0.71 & 0.07 & 0.82 \\
\hline SEM & $0.17^{*}$ & $0.28^{*}$ & $0.08 \mathrm{NS}$ & $0.09 \mathrm{NS}$ & $0.07 \mathrm{NS}$ & $0.09 \mathrm{NS}$ \\
\hline
\end{tabular}

Mean values followed by the same letter are not significantly different at $\alpha=0.05$ by Tukey's HSD

NS (Not significantly different $\alpha=0.05$ )

*(Significantly different at $\alpha=0.05$ ) 
Results in Table 3 revealed that the nematodes have preference for different crops, even though the mean numbers of the isolated nematodes were not different significantly $(p>0.05)$ for the crops. It was shown that Meloidogyne sp. was most predominant in cowpea and soybean with mean numbers of 1.1 and 1.21 respectively, Helicotylenchus sp. was most predominant in Celosia sp. and soybean with mean numbers of 1.41 and 1.44 respectively. Celosia sp. appears to be the host for largest number of Scutellonema sp. (0.89), Pratylenchus sp. (0.89) and Tylenchus sp. (0.94), while Teak had the lowest number of almost all the nematodes. 
Table 3: Occurrence (Mean number) of Nematodes in the Rhizosphere of the selected crops in Kwara State

Mean number of Nematodes $200 \mathrm{~g}-{ }^{1}$ dry weight of soil

\begin{tabular}{lcccccc} 
Crops & $\begin{array}{l}\text { Meloidogyne } \\
\mathrm{sp} .\end{array}$ & $\begin{array}{l}\text { Helicotylenchus } \\
\mathrm{sp} .\end{array}$ & $\begin{array}{l}\text { Scutellonema } \\
\mathrm{sp} .\end{array}$ & $\begin{array}{l}\text { Pratylenchus } \\
\mathrm{sp} .\end{array}$ & $\begin{array}{l}\text { Rotylenchus } \\
\mathrm{sp} .\end{array}$ & $\begin{array}{l}\text { Tylenchus } \\
\mathrm{sp} .\end{array}$ \\
\hline Celosia sp. & 0.8 & 1.41 & 0.89 & 0.89 & 0.71 & 0.94 \\
Cowpea & 1.1 & 1.3 & 0.71 & 0.71 & 0.71 & 0.8 \\
Maize & 0.8 & 1.32 & 0.8 & 0.8 & 0.85 & 0.71 \\
Soybean & 1.21 & 1.44 & 0.71 & 0.89 & 0.71 & 0.71 \\
Teak & 0.99 & 0.89 & 0.71 & 0.71 & 0.71 & 0.71 \\
\hline SEM & $0.15 \mathrm{NS}$ & $0.26 \mathrm{NS}$ & $0.07 \mathrm{NS}$ & $0.09 \mathrm{NS}$ & $0.07 \mathrm{NS}$ & $0.08 \mathrm{NS}$ \\
\hline
\end{tabular}

Mean values followed by the same letter are not significantly different at $\alpha=0.05$ by Tukey's HSD

NS (Not significantly different at $\alpha=0.05$ ) 


\section{Discussion}

This study showed that there were differences in population of nematodes in the soils sampled in Kwara State, Nigeria. There was diversity in the population of Meloidogyne sp. and Helicotylenchus $\mathrm{sp}$. at the different sampled locations which showed nematodes preference for particular sampled soils. The difference in the population may be due to difference in soil moisture and temperature regimes of the different agro-ecologies of the sampled locations. Soil moisture in particular determines nematodes activity rate and food provisions, and consequently changes in its availability may directly impact soil nematode development and community composition (Steinberger et al. 2001)

Incidentally, temperature and moisture difference are the major factors that characterised the study areas into the different agro-ecological zones. The forest zone with higher soil moisture and lower temperature supported larger population of the nematodes than the savannah zones with lower soil moisture and higher temperature. The predominance of certain nematodes in certain soil types as observed in this study may be as a result of preference of the nematodes for the crops grown on the soils.

\section{CONCLUSION AND RECOMMENDATIONS}

This study revealed that the population of nematodes in the different sampled soils differed. The differences were as a result of the agroecological disparity in the different study areas. Nematodes population was higher in the forest agro-ecology than the savanna agro-ecology. Meloidogyne sp. and Helicotylenchus sp. were the most predominant nematodes in most of the crops in the sampled soils.

\section{REFERENCES}

Afolami S., Solomon S. and Daramola F. (2014) Biodiversity of plant- parasitic nematodes of Sugarcane in Bacita, Nigeria. Journal of Entomology and Nematology 6(6): 71 - 79.

Armen, C. Tarjan, R. Esser, T and Shih, C. I. (1977). An illustrated key to nematodes found in freshwater. WPCF., pp: 2318-2337.

Baba, H. S. Izuogu N. B. Olajide, M. C. Dosunmu, O. O. Ahmed, O. and Saliu, A. R. (2018). Pathogenicity of Meloidogyne incognita in Selected Groundnut Varieties and its Management with Aqueous Leaf Extracts of Wild sage (Lantana camara L.) and Locust bean (Parkia biglobosa Jacq.). Agrosearch 18 (2): 1 - 14

Chitwood, D. J. (2002). Phytochemical based strategies for nematode control. Annual Review Phytopathol., 40: 221-249. 
Chitwood, D. J. (2003). Research on plant-parasitic nematode biology conducted by the United States Department of Agriculture-Agricultural Research Service. Pest Management Science., 59: 748-753.

Egunjobi, O. A. (2014). Nematode and man's welfare. Nigerian journal of Nematology 2: 3-7

Galip, K. (2007). Effects of soil solarization and organic amendment treatments for controlling Meloidogyne incognita in tomatoe cultivars in western Anatolia. Turkish Journal of Agriculture and Forestry., 31: 159-167.

Gregory, C. B Marceline, E and Conrad, B (2017). The impact of Plant Parasitic Nematodeson Agriculture and Methods of Control. Nematology Concepts, Diagnosis and Control, Mohammad, M. S and Mohammad, M Intech Open DOI: 10.5772/intechopen. 68958. Available from: https://www.intechopen.com/books/nematology-concepto-diagnosis-andcontrol/the-impact-of-plant-parasitic-nematodes-on-agriculture-and-methods-of-control

Ingham, R. E. and Moidenke, A. (2000). Soil and water conservation Society. Soil biology Primer. Rev. Ed. Ankeny, lowa: Soil and water Conservation Society. www.gov/sgi/concepts/soilbiology/biology.html. Accessed on 12/10/2017.

Jackson T. H. (1962). Nematode control trials at Thika, Kenya. In 1960 CCTA Inter-African Plant Nematology Conference, pp. 21-22. Kikuyu, Kenya: CCTA

Kleynhans, K. P. (1999). Collecting and preserving nematodes. A manual for nematology. www.cassavabiz.org/..../NEM-SCR.Pdf. Accessed on 23/10/2012.

Lambert, K. and Bekel, S. (2002). Introduction to plant parasitic nematodes. The plant Health instructor. The plant Health instructor.

Nchore, S.B. Waceke, J.W. and Kariuki, G.M. (2010) Incidence and prevalence of root-knot nematode Meloidogyne species in selected indigenous leafy vegetables in Kisii and TransMara Counties of Kenya. In: Transforming Agriculture for improved livelihoods through Agricultural Product Value Chains. 12th KARI Biennial Scientific Conference, November 8-12, 2010, Nairobi, Kenya. KARI, pp. 675-681.

Nchore , S., Waceke, J. W., and Kariuki, G. M. (2011). Use of agro-industrial waste and organic amendments in managing root-knot nematodes in black night shade in selected parts of Kenya. Paper presented at the 10th African Crop Science Conference Proceedings, Maputo, Mozambique Nematophagous Fungi in Soil Visualized by Low Temperature Scanning Electron Microscopy. Mycologia., 92: 10-15.

Noling, J. W. (2012). Movement and Toxicity of Nematicides in the Plant Root Zone. edis.ifas.ufl.edu/ng002 Accessed on 15/11/2012. 
Ndana, R. W. Oyedunmade, E. E. A. (2010). In-vitro studies of effectiveness of plant extracts compared to Carbofuran in Controlling the Root Knot Nematode Meloidogyne incognita. Agrosearch 10 (1\&2): 1-10

Okafor O. E., Ugwuoke K. I., Mba C. L., Okafor F. C. and Mbadianya J. I. (2015). The distribution of plant-parasitic nematodes of Musa spp. in Nsukka Agricultural Ecological zone, Enugu State, Nigeria. African Journal of Agricultural Research. 10(48): 4338-4347

Oyedunmade, E. E. A and Izuogu, N. B. (2011). Efficacy of Aqueous Extract of Lemon Grass (Andropogon citratus L.) against Root-Knot Nematode Pests of Okra. (Abelmoschus esculentus (L.) Moench). Agrosearch 11 (1\&2): 31 - 38

Steinberger, Y., Liang, W., Savkina, E., Meshi, T., and Barness, G. (2001). Nematode community composition and diversity associated with a topoclimatic transect in a rain shadow desert. European Journal of Soil Biology., 37: 315-320.

Talwana H, Sibanda Z, Wanjohi W, Kimenju W, Luambano-Nyoni N, (2016). Agricultural nematology in East and Southern Africa: problems, management strategies and stakeholder linkages. Pest Management Science, 72:226-45 